\title{
Effect of Glacial Retreat on Floral Distribution and/or Displacement in Khersan Glacier, Central Alborz Mountain range, Iran
}

\section{Kourosh Kavousi ${ }^{1}$, Taher Nejadsattari ${ }^{1 *}$, Yunes Asri², Hamid Ejtehadi ${ }^{3}$ Ramezan ali Khavari-Nejad ${ }^{1}$}

'Department of Biology, Science and Research Branch, Islamic Azad University, Hesarak-1477893855, Tehran. Iran

${ }^{2}$ Research Institute of Forest and Rangelands, National Botanical Garden of Iran, P.O. Box 13185-116, Tehran, Iran

${ }^{3}$ Department of Biology, Faculty of Science, Ferdowsi University of Mashhad, Azadi Square, Mashhad 9177948974, Iran

Study Area: Khersan glacier valley, Alam kuh mont., Mazandaran and Tehran provinces, Iran

Coordinates: $36^{\circ} 21^{\prime} 45^{\prime \prime} \mathrm{N}, \quad 50^{\circ} 57^{\circ} 07^{\prime \prime E}$ to $36^{\circ} 21^{\prime}$ oo" $\mathrm{N}$, $50^{\circ} 59^{\prime} \mathrm{oo}^{\prime \prime} \mathrm{E}$

Key words: Alam kuh, Nival, Alpine, Plant displacement , Floral relocation

\section{Introduction:}

Plant species responds independently to the ecological changes. The plants' behavior in response to alteration in temperature is very diverse.(Cannone et al., 2008). Various plant species earlier reported from Khersan glacier territory are now extinct. The alterations in slope and height due to displacement occurs on both the sides of Khersan glacier in Marji-Kash southern slope and Menar kuh in northern slope which is an active glacier in Alam kuh mountain series. Khersan glacier located on the southern border of Mazandaran province cover twokilometer length, i.e., $\sim 400 \mathrm{~m}$ width and 40 meter deep (freeze) with $7 \mathrm{~m}$ annual movement (Mizuno, 2005).

For this particular zone (central Alborz), in 1843 Kotschy listed the plant species for the first time which was published later in a series Kotschy (1861a,b). Further time to time revised by, Bornmuller (1904), Melchior (1937) and Klein (1972). On our recent database tabulations done in between the year 2013-2015, we included all the earlier reported species up until the year 1972, where the species get increased from 31 to 71
Abstract

During past few decades, worldwide various ecological alterations have been experienced after treat and decreasing of glaciers. Notable changes have been traced in Khersan glacier, Central Alborz of Iran by monitoring since 2013 to 2015. According to our studies, Khersan glacier surface reduced since 1991 and this significant reduction led to many ecological alterations. Species elimination close to the glacier, displacement of various flora from sub-Alpine to Alpine and Nival area including changes in floral frequency are notable alterations taken during glacier retreat. A large number of studies in Khersan glacier area since last two centuries have evidenced complete elimination of 6 plant species. Displacement of 16 plant species during recent years revealed that such species after retreat either found a new location for the establishment or got eliminated. Besides natural changes, the glacier area was also affected by man-made developments. Perhaps new condition puts many plant species in conservation level which need proper care programs. In this study multidimensional scaling model (MDS) is used to show the Nival areas where species are under much stress. Proper evidence has been tried to put forward for describing such changes.

flowering and Pteridophyte plant species. However, reports on Draba melanopus, Pseudocamelina Kleinii, Barbarea stricta, Didymophysa Fedtschenkoana, Crepis multicaulis subsp congesta are for the first time from Iran.

\section{Material and Methods:}

We prepared a base map in GIS system and glacial condition, images taken in suitable daylight conditions, prepared images and processed for, determination of glacier surface in the study area. The land sat images 8.7 ETM+, 5TM have been processed to identify the glacier changes and compared with the images which have been used in the period 1991 to 2014 for investigates glacier surface reduction in this interval. Field surveys were made for verif ication of the available information. Earlier works since Kotschy (1861a,b) have been cross checked and a full list of plant species reportedly has been extracted and field survey was done over three years to update floristic data. The botanical survey was completed along two longitudinal lines 'a', 'b' from 3650 meters to 4453 meters in the north of Marjikash mountain and 4134 meters in the 
south of Menarkuh (Fig.- 2). During the survey, 35 fixed quadrate have been considered for determining ecological zones, their borders along with with floral tabulations were made in between 2013 to 2015. According to the relationship between the number of species to the surface, minimum surface of quadrate on both side of the glacier was determined and plant species existing in each quadrate was tabulated and determined with Flora Iranica, Flora of Russia and Flora of Afghanistan (Komarov, 1939; Breckle, 2007; Sharpe et al., 2008).

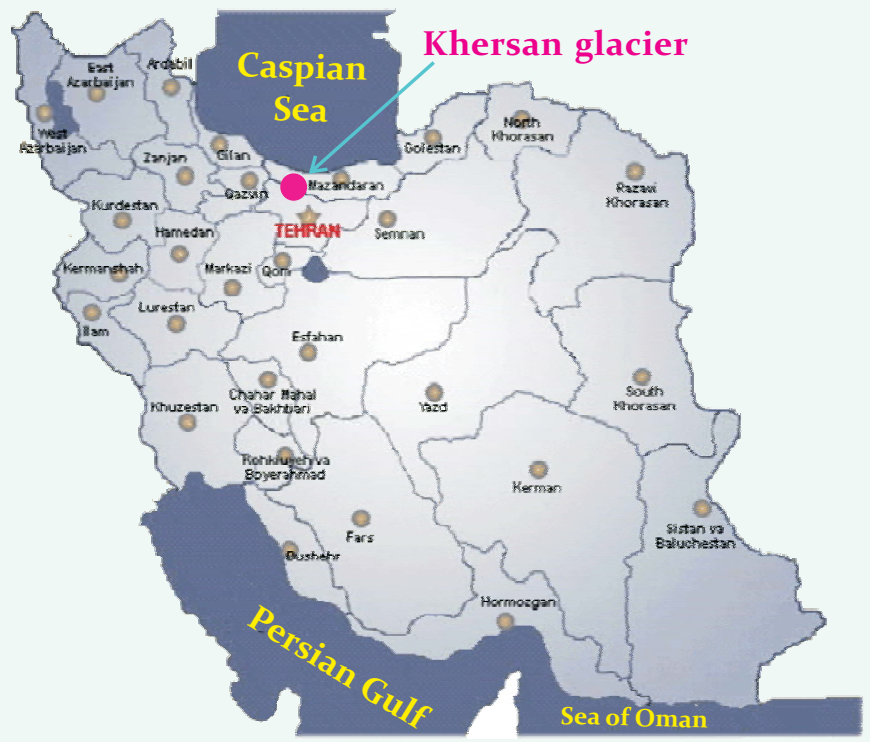

Figure-1: Khersan glacier location

Abundance and dominance are calculated to show variations of plant species in each quadrat series during three year and multidimensional scaling model was used to show vegetation change and transition boundary in both lines.( Erschbamer et al., 2011). It begins from 4121 meters in Menar slope and 4226 meters in the north of Marjikash mountain (fig.-3).

\section{Results}

Processing of spatial images in Khersan glacier territories and Hesar-e Chal valley proves that the reduction of glacier took place in the large surface and which effects the environmental factors drastically such as tempreture. Since 1991, Khersan glacier area has been decreased in its surface, which can be verified from the Figure-4, the spatial evidence for changing of glacial area; a large area reduction in Khersan glacier during 1991 to 2014.

One of the main issues in the ecology of glacial plants is altitudinal alterations among sub-Alpine, Alpine and Nival. Such relevant positioning data helps to interpret the situation of plant at present and future, their ultimate response to the new environmental factors and finally the climbing conditions of the species to higher altitudes i.e., up to what height it can be continued in future, which is important in terms of sustainability and what care is

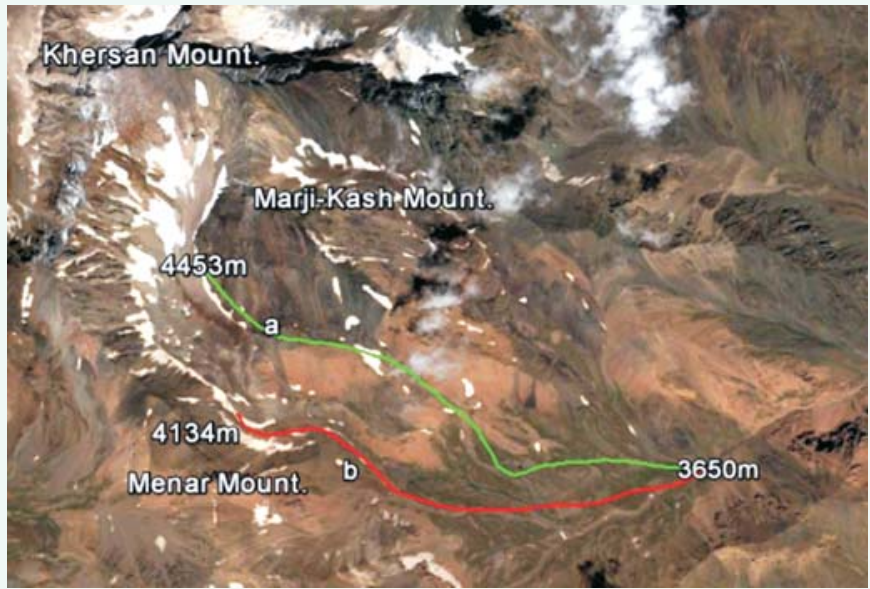

Figure-1: Line of a, b, from 3650 to 4453 meters for botanical survey in Khersan glacier territory

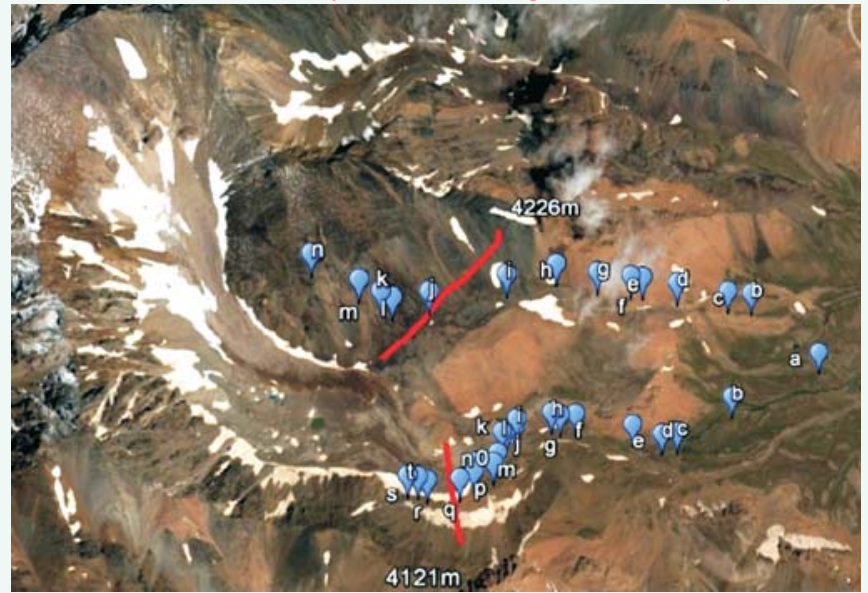

Figure-3: Elevation zones such as Alpine and Nival and their borders in Khersan glacier territory

needed to conserve such native species. Survey on 35 fixed quadrate data conducted on both the sides of Khersan glacier in Marji-Kash and Menar slopes shows different height for the transition between Alpine and Nival in each side of glacier. Multidimensional scaling (MDS) and other ecological remarks proved the different natural border for this transition (Sharpe et al., 2008). Transition borders at Marji-Kash slope is recognized in 4226 meters which is visibleafter quadrate J and for Menar slope it is in 4121 meters after quadrate $q$ in this side. An ecological study provides other indicators for entering the Nival zone and passing from Alpine area. Diminished biodiversity and occupancy in quadrate, present of few specif ic species in some particular quadrate and respective survival of species which are usually affected by the unfavorable environmental condition are major factors for recognition of such border. Moreover according to Multidimensional scaling model, in harsh environmental area mean Nival zone, quadrates close together. Figure 5 demonstrated MDS model in both slopes of Khersan glacier in Menarand Marji-Kash. This figure shows that in Menar side quadrate q, r, s, t comes 

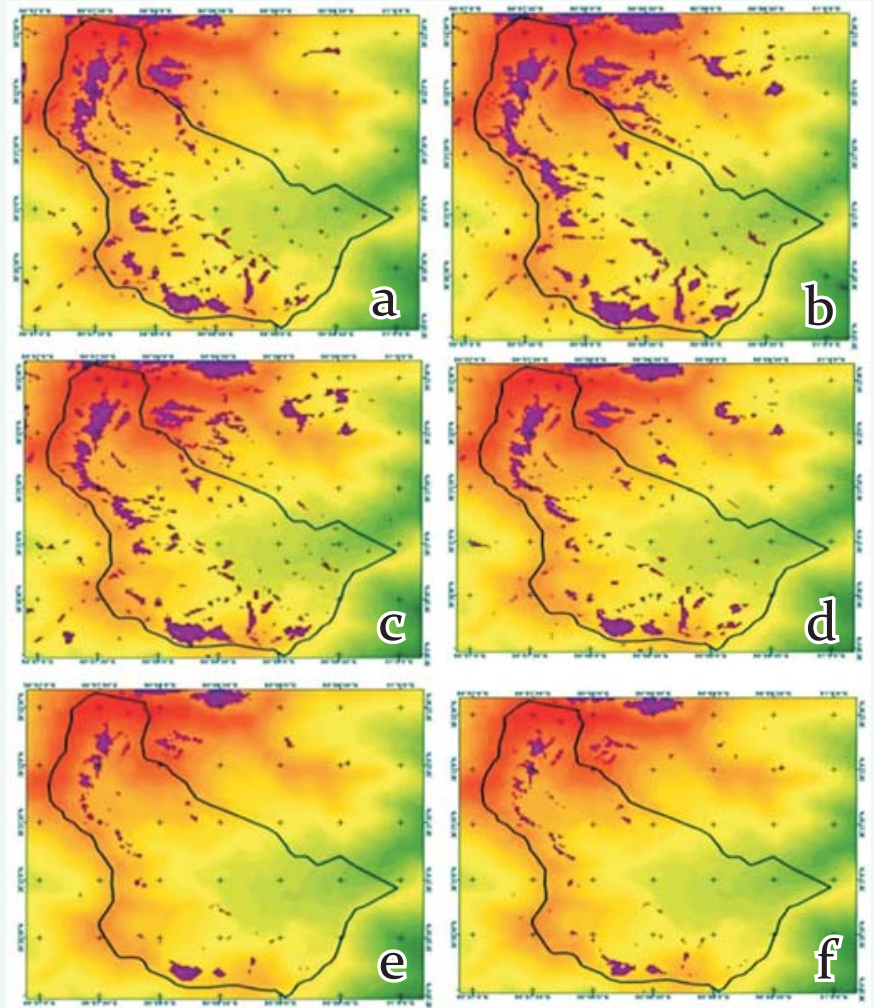

Figure-4: changes of glacial areain Khersan during 1991 to 2014. a) 1991 (120 ha); b) 1993 (135 ha) c) 1998 (117 ha) d) 2006 (84 ha) e) $2013(33.5 \mathrm{ha})$ f) 2014 ( $32 \mathrm{ha})$

together in Nival from 4226 meters and in Marji-Kash side, quadrate $\mathrm{j}, \mathrm{k}, \mathrm{l}, \mathrm{m}$, $\mathrm{n}$ belong to Nival condition and started in 4121 meters (Gottfried, 2006).

On the basis of our field investigation and the studies conducted since 1843 , four types of species movement i.e., from one place to another has been recognized. Few species such as Senecio vulcanicus, Cerastium cerastioides, Scorzoera radicosa demonstrarted in White routes have moved from sub-Alpine to Alpine area, Alopecurus textilis, Oxytropis hirsutisula, Arabis caucasica, Bromus brachystachus, Senecio vulcanicus, Festuca ovina have moved from sub- Alpine to Nival area (Red routes), Oxytropis immersa and Erigeron uniflorus subsp elbursensis have moved from higher land of Alpine zone to Nival (Brown routes) and many species such as Pseudocamelina Kleinii, Veronica paederotae, Draba melanopus, Didymophysa Fedtschenkoana, Polygonum serpyllaceum have moved from Alpine to Nival area (Yellow rout). Figure 6 showing major routes for natural migration from a low level to Alpine and Nival ecological condition and table - 1 presents altitude and longitude relocation according to previous data and recent experiment in 2013 to-2015 (Rechinger, 2010).

\section{Discussion:}

To discuss our findings we are splitting the objective into two separate headings; a) the border of Alpine and Nival
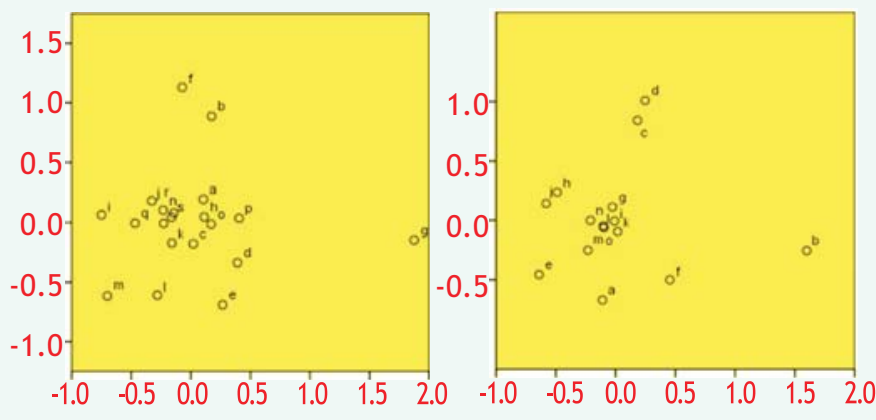

Figure-5: MDS model in Menar(left) and MarjiKash(right) at their quadrate series

ecological zone; b) conservation of sensitive and threatened species.

Alpine - Nival borderline: on the basis of fig.- 1, the movement in species can be classified into two main groups. In the first group, species shifted from sub-Alpine to Alpine and Nival and the second group includes the species which were shifted from Alpine to higher Alpine land and Nival ecological condition. Other studies have shown that some species such as Didymophysa aucheri and Dracocephalum aucheri have never been in Alpine and only belong to Nival area. Didymophysa fedtschenkoana which is recorded for the first time from Iran lives in Nival area in Afghanistan and basically is descendent of Nival glacial area.

The quadrate series from J placed in Nival and two species Didymophysa aucheri and Dracocephalum aucheri were belong to Nival area so we were forced to accept it that the Nival border has shifted upward in recent years from 4100 meters to 4250 meters at Marji-Kash slope. In the Menar glacial slope, the species Pseudocamelina kleinii and Veronica paederotae have moved upward from 3580 meters and 3900 meters to 4124 meters and 4134 meters.

The habitat of these species is essentially belongs to the Nival area and life cycle depend on glacier condition. It represent that the Nival border climbed upward during glacier retreat in Menar slope from 3800 meters to 4121 meters and cited after quadrateq.

Conversation value and plan: although each habitat has specific ecological importance, but the glacial plant exhibit very limited growth and these areas possess some specific species only. Some species such as Oxytropis immersa and Erigeron uniflorus subsp elbursesis are found near the Nival boundary in the Alpine and single entry to the Nival borderline. So conservational strategy is mainly required for two groups; one which are critically endangered having a limited distribution such as Pseudocamlina kleinii, Didymophysa fedtschenkoana and Dracocephalum aucheri whereas the second includes plant species distributed between Alpine and Nival area. Many species belongs to Astragalus and Oxytropis genus support ecological condition for the establishment of 
sensitive species. At Menar this criterion defines up to 4050 meters for Astragalus macrosemius and it was seen to replace with Oxytropis immersa at higher attitude. In Marjikash glacier slope this is due to Astragalus aureus at below 4000 meters and it supported with other species Oxytropis immersa, Oxytropis Takhti-Soleimani, Oxytropis hirsutiscula between 4000 and 4200 meters below Alpine-Nival borderline.

Rare plants due to glacier condition in Nival area and nurse plant in Alpine and Nival classified as protected species which cares for other species establishment also. These species which show in Table 2 require a proper conservation program. Table 2 presented plant species conservation value based on IUCN (2001) categories.

\section{- Conversation plan}

Because our territory is not supported with IUCN organization conservation program and local protection plan are not getting ground for success. Nevertheless, there are considered following plan for conservation of critically endangered, Endangered and Vulnerable plant species; According to a new study conducted at the other site of Alborz mountain series, Azad kuh and Demavand mountain success has been achieved to protect many of rare plant species of Nival area. For Example, Pseudocamelina kleinii has previously reported from Azad kuh and northeast slope of Demavand mountain are supporting a small population of Didymophysa aucheri , so it is possible to protect these location as support areas and we have to develop these vegetation communities (Ghelichnia, 2014).

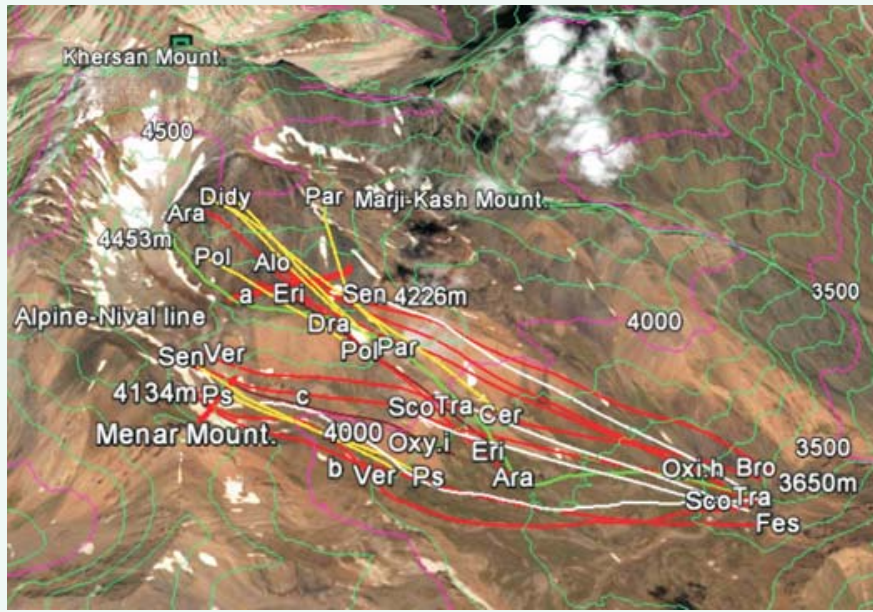

Figure 6 . Species list and major migration ways from low level to highlands in Alpine and Nival ecological condition. Dra.; Dracocephalum Aucheri, Cer.; Cerastium cerastioides, Sen.; Senecio vulcanicus, Alo., Alopecurus textilis, Bro.; Bromus brachystachyus, Ara.; Arabis caucasica; Ver.; Veronica paederotae, Oxy.hi.; Oxytropis hirsutiscula, Oxy.i.; Oxytropis immersa, Eri.; Erigeron uniflorus, Didy.; Didymophysa Aucheri, Pol.; Polygonum serpyllaceum, Ps. ; Pseudocamelina Kleinii, Tra.; Trachydium pauciradiatum Sco.; Scorzonera radicosa, Fes.; Festuca ovina

\begin{tabular}{|c|c|c|c|c|c|}
\hline \multicolumn{6}{|c|}{ Tableı. Plant species relocation } \\
\hline \multirow[b]{2}{*}{ Code } & \multirow[b]{2}{*}{ species } & \multirow[b]{2}{*}{ Family } & \multicolumn{2}{|c|}{ Altitude relocation } & \multirow[b]{2}{*}{$\begin{array}{l}\text { Longitude } \\
\text { Relocation (m) }\end{array}$} \\
\hline & & & $\begin{array}{l}\text { Previous data } \\
(1884-1972)\end{array}$ & $\begin{array}{l}\text { New Data in } \\
(2013-2015)\end{array}$ & \\
\hline 1 & Pseudocamelina Kleinii & Brassicaceae & 3850 & 4127 & 1466 \\
\hline 2 & Veronica paederotae & Scrophulariaceae & 3900 & 4134 & 1690 \\
\hline 3 & Arabis caucasica & Brassicaceae & 3800 & 4400 & 2269 \\
\hline 4 & Dracocephalum Aucheri & Lamiaceae & 4155 & 4435 & 1180 \\
\hline 5 & Cerastium cerastioides & Caryophyllaceae & 3900 & 4435 & 2276 \\
\hline 6 & DidymophysaAucheri & Brassicaceae & 4100 & 4353 & 1380 \\
\hline 7 & Oxytropis hirsutiscula & Fabaceae & 3650 & 4250 & 2650 \\
\hline 8 & Oxytropis immersa & Fabaceae & 3800 & 4200 & 1330 \\
\hline 9 & Erigeron uniflorus & Asteraceae & 3850 & 4226 & 2400 \\
\hline 10 & Trachydium pauciradiatum & Apiaceae & 3650 & 4000 & 1488 \\
\hline 11 & Scorzonera radicosa & Asteraceae & 3650 & 4000 & $155^{0}$ \\
\hline 12 & Senecio vulcanicus & Asteraceae & 3620 & 4200 & 2450 \\
\hline 13 & Polygonum serpyllaceum & Polygonaceae & 4100 & 4300 & 800 \\
\hline 14 & Bromus brachystachyus & Poaceae & 3500 & 4066 & 1400 \\
\hline 15 & Alopecurus textilis & Poaceae & 3500 & 4200 & 1500 \\
\hline 16 & Festuca ovina & Poaceae & 3400 & 4127 & 1450 \\
\hline
\end{tabular}




\begin{tabular}{|c|c|c|c|c|c|}
\hline \multirow[b]{2}{*}{ Plant species } & \multirow[b]{2}{*}{ Family } & \multirow[b]{2}{*}{ En } & \multicolumn{3}{|c|}{ Conservation Value } \\
\hline & & & $\mathrm{Cr}$ & En & Vl \\
\hline Pseudocanelma Kleinii & Cruciferae & * & * & & \\
\hline Didymophysa Aucheri & Cruciferae & * & & * & \\
\hline Didymophysa Fedtschenkoana & Cruciferae & & & * & \\
\hline Veronica paederotae & Scrophulariaceae & * & & * & \\
\hline Erigeron uniflorus subsp elbursensis & Asteraceae & * & & & * \\
\hline Astragalus macrosemius & Papilionaceae & * & & * & \\
\hline Oxytropis immersa & Papilionaceae & * & & * & \\
\hline Oxytropin Takhti Soleimanii & Papilionaceae & * & & * & \\
\hline Oxytropis hirsutiscula & Papilionaceae & * & & * & \\
\hline Draba melanopus & Cruciferae & & & * & \\
\hline Dracocephalum Aucheri & Labiatae & * & & & * \\
\hline
\end{tabular}

En.- Endemic; Cr.- Critically endangered, En.- Endangered, Vul.-Vulnerable

\section{Acknowledgements:}

We would like to thank the Islamic Azad University- Tehran Science and Research Branch for providing the facilities that were necessary to carry out the work. I wish to express my gratitude to Professor Mozaffarain, Professor Hamdi, Professor Zehzad and Professor Mizuno for their valuable botanical and ecological advices and Mr.Sharifi, the retired gamekeeper environmental guard for his effective environmental comments during all botanical tours. We would like to thank Mr.Ashayerii and Mr.Asilian, soil specialist, for their advices in regard to khersan valley and Dr.Abassian environmentalist for his assistant in all fields visit during recent years and his valuable information about big mammals grazing food chain due to Khersan valley and their conservation values.

\section{References:}

Bornmuller, J. (1906): Beitrage zur Flora der Elburzgebirge NordPersiens. Bull Herb Boiss. Geneve. 6: 605-620,765-780.

Breckle, S.W.(2007): Flora and vegetation of Afghanistan. Basic Appl. Dryland Res., 1 (2): 155-194.

Cannone, N., Diolaiuti, G., Guglielmin, M. \& Smiraglia, C. (2008): Accelerating climate change impact on Alpine glacier Foref ield ecosystems in the European Alps. Ecol.Appl., 18 (3): 637-648.

Erschbamer, B., Unterluggauer, P., Winkler, E. \& Mallaun, M. (2011): Changes in plant species diversity revealed by longterm monitoring on mountain summits in the Dolomites (northern Italy). Preslia, 83:387-401.

Ghelichnia, H.(2014): Flora and vegetation of Mt. Damavand in Iran. Phytologia Balcanica, 20(2-3):257-265.
Gottfried, M. (2006): Changing vegetation pattern sat the Alpine-Nival ecotone: Recent results from a GLORIA mastersitein the Central Alps. Austrian Academy of Sciences and University of Vienna, Vienna.

IUCN.( 2001): IUCN Red List Categories and Criteria, Version 3.1. Prepared by the IUCN Species Survival Commission. IUCN, Gland, Switzerland, and Cambridge, United Kingdom.

Kotschy, T. (1861a): Die Vegetation des westlichen Elbrus in Nordpersien. Osterr Bot Zeitschr, 11(4): 105-117.

Kotschy, T. (1861b): Der westliche Elbrus bei Teheran. Mitt. der K. K. Oester Geogr Gesell Wien, 5: 65-110.

Komarov, V.L. (1939): Flora of USSR, Botanical Institute of the Academy of Sciences of the U.S.S.R. Izdatel'stvo Akademii NaukSSSR Moskva-Leningrad. 8: 276-237.

Klein, J.K. (1982): Les groupments chinphilesde l' Alborz central (Iran). Comparasion avec lears homologues d' Asia centrale. Phytocoenologia, 10:463-485.

Melchior, H. (1937): Zur pflanzengeographie ddes Elburs-Gebirges in Nord-Iran. Sber Ges NaturfFreunde Berl., 1937: 55-71.

Mizuno, K. (2005): Vegetation succession in relation to glacial fluctuation in the high mountains of Africa. African Stud Monogr Suppl., 30:195-212.

Rechinger, K.H. (ed) (1963-2010): Flora Iranica, vols 1-178. Akad. Druck-u. Verlagsanstalt Graz.

Sharpe, C., Grant, L. \& Domes, K. (2008): Plant Community Analysis and Dating of the Asulkan Glacier, A study of plant community succession over time in a glacial forefield,.Department of geography, University of Victoria. 